\title{
Correction: Metabolic biomarker signature to differentiate pancreatic ductal adenocarcinoma from chronic pancreatitis
}

Mayerle J, Kalthoff H, Reszka R, et al. Metabolic biomarker signature to differentiate pancreatic ductal adenocarcinoma from chronic pancreatitis. Gut 2017;67:128-37. doi: 10.1136/ gutjnl-2016-312432

The colour keys in the figure 4 legend have been corrected to read:

(A) Score of the pancreatic biomarker signature identified in the training set and applied on the test set. Non-pancreatic controls in grey $(n=80)$, chronic pancreatitis in green $(n=80)$ and pancreatic cancer in magenta $(n=79)$. Box plots give median, upper quartile and lower quartile by the box and the upper adjacent and lower adjacent values by the whiskers. The upper adjacent value is the largest observation that is less than or equal to the upper inner fence, which is the third quartile plus 1.5-fold IQR. The lower adjacent value gives the corresponding value for downregulation. The diagnostic cut-off of the pancreatic biomarker score was set to $\geq 0.384$. (B) Scatter plot for graphical representation of the biomarker signature score. Classifiers are the biomarker signature generated in the training set and presented here for the test set. Y-axis score of biomarker signature with the cut-off of $\geq 0.384$ and CA19-9 on the $X$ axis with the cut-off $\geq 37 \mathrm{U} / \mathrm{mL}$. Chronic pancreatitis in green circles $(n=80)$ and pancreatic cancer in magenta circles $(n=79)$. Numbers give subjects that benefit from the biomarker signature and all numbers in the respective area of the plot.

\section{(6) \\ OPEN ACCESS}

Open Access This is an Open Access article distributed in accordance with the Creative Commons Attribution Non Commercial (CC BY-NC 4.0) license, which permits others to distribute, remix, adapt, build upon this work noncommercially, and license their derivative works on different terms, provided the original work is properly cited and the use is non-commercial. See: http://creativecommons.org/licenses/by-nc/4.0/

(C) Article author(s) (or their employer(s) unless otherwise stated in the text of the article) 2018. All rights reserved. No commercial use is permitted unless otherwise expressly granted.

Gut 2018;67:994. doi:10.1136/gutjnl-2016-312432corr1

Check for updates 